\title{
Minkkien uusi jalostusarvostelu
}

Minna Koivula ja Ismo Strandén

MTT, Biotekniikka- ja elintarviketutkimus, Biometrinen genetiikka, 31600 Jokioinen

e-mail.etunimi.sukunimi@mtt.fi

\section{Tiivistelmä}

Turkistuotannossa jalostuksen tavoitteena on kasvattaa nahan kokoa ja pentuekokoa sekä parantaa nahan laatua ja värin puhtautta. Minkeillä jalostus perustuu pääsääntöisesti pentuekokoon sekä elävistä eläimistä arvioitaviin gradeerausominaisuuksiin, joita ovat eläimen koko, värin puhtaus, värin tummuus, karvan massakkuus, peittävyys ja laatu.

Minkkien jalostusarvostelussa käytettävät tilastolliset mallit muutettiin alkuvuonna 2007. Vanhassa arvostelussa kaikille ominaisuuksille käytettiin samaa mallia. Mallissa kiinteänä tekijänä oli tila-vuosi ja satunnaistekijöinä perinnöllinen eläintekijä sekä jäännöstekijä. Pentuekoossa havaintona käytettiin naaraan kaikkien pentuehavaintojen keskiarvoa. Kaikkilla ominaisuuksilla periytymisasteena oli 0,20 .

Uudessa arvostelussa gradeerausominaisuuksien malliin otettiin mukaan kiinteiksi tekijöiksi eläimen sukupuoli, syntymäajankohta ja emän ikä. Lisäksi pentue lisättiin satunnaistekijäksi. Pentuekoon malliin lisättiin uusiksi kiinteiksi tekijöiksi naaraan ikä ja paritusten lukumäärä. Satunnaistekijäksi lisättiin naaraan pysyvät ympäristövaikutukset. Uudessa arvostelussa pentuekoon jalostusarvot lasketaan siis toistuvuuseläinmallilla. Periytymisasteet muuttuivat melko vähän paitsi pentuekoolla ja värin puhtaudella. Vaikka uusien mallien myötä eläinten jalostusarvot muuttuvat, käytännössä uudet minkkimallit vaikuttavat eläinten valintaan melko vähän. Muutosten suuruus vaihtelee tietenkin tiloittain, mutta keskimäärin muutokset ovat melko hillittyjä.

Asiasanat: minkki, jalostusarvostelu, periytymisaste, koko, pentuekoko 


\section{Johdanto}

Turkisjalostuksen tavoitteena on kasvattaa nahan kokoa ja pentuekokoa sekä parantaa nahan laatua ja värin puhtautta. Tärkein nahan hintaan vaikuttava ominaisuus on nahan koko (Lindh ja Lohi 1999 ja Lohi 2002). Kun huomioidaan myös nahan tuotantokustannukset, nahan laatu ja pentuekoko nousevat tarhaajien kannalta tärkeimmiksi ominaisuuksiksi (Peura ym. 2005).

Minkkien jalostusarvot lasketaan tilakohtaisesti eli jalostusarvot eivät ole vertailukelpoisia tilojen välillä. Lisäksi ominaisuuksien välisiä geneettisiä korrelaatioita ei huomioida. Vuoden 2007 alkuun saakka minkkien jalostusarvostelut laskettiin samalla tilastollisella mallilla kaikille ominaisuuksille. Havainnoista korjattiin tiloittain vuosien aiheuttama vaihtelu. Lisäksi kaikkien ominaisuuksien periytymisaste oli 0,20 . Koska ominaisuuksien periytyvyys oli todellisuutta suurempi tai pienempi, sukulaisten havainnot vaikuttivat minkin jalostusarvoon liian vähän tai liian paljon. Vanhassa mallissa pentuekoon havaintona käytettiin yksilön kaikkien havaintojen keskiarvoa. Keskiarvon käyttäminen pentuekoon jalostusarvostelussa vähentää ominaisuudessa esiintyvää geneettistä vaihtelua. Tutkimuksen tavoitteena oli uudistaa minkkien jalostusarvostelujen tilastolliset mallit sekä arvioida arvostelussa tarvittavat varianssikomponentit.

\section{Materiaali ja menetelmät}

Aineisto poimittiin Suomen Turkiseläinten Kasvattajain Liiton ylläpitämästä SAMPO jalostusohjelmasta. Kaikkiaan aineistossa oli 99861 minkkiä vuosilta 1989 - 2006 ja sukupuussa oli 148425 eläintä 37 tarhalta. Taulukossa 1 on kuvaus analyyseissä käytetystä aineistosta.

Taulukko 1. Pentuekoon sekä gradeerauominaisuuksien perinnöllisten tunnuslukujen laskennassa käytettyjen havaintojen määrät (n), keskiarvot, keskihajonta (SD) sekä vaihtelukerroin (CV)

\begin{tabular}{lcccc}
\hline Ominaisuus & $\mathrm{n}$ & keskiarvo & $\mathrm{SD}$ & $\mathrm{CV}$ \\
\hline Pentuekoko & 77911 & 5,65 & 2,10 & 0,37 \\
Eläimen koko & 90134 & 3,62 & 0,88 & 0,24 \\
Värin puhtaus & 48108 & 3,43 & 0,84 & 0,24 \\
Värin tummuus & 61074 & 3,71 & 0,77 & 0,21 \\
Massakkuus & 62078 & 3,66 & 0,82 & 0,22 \\
Peittävyys & 34607 & 3,58 & 0,98 & 0,27 \\
Laatu & 74463 & 3,70 & 0,78 & 0,22 \\
\hline
\end{tabular}

Varianssikomponenttien laskennassa käytettiin DMU ohjelmaa (Madsen ja Jensen 2000). Gradeerausominaisuuksille käytettiin mallia:

ja pentuekoolle:

$$
\mathbf{y}=\mathbf{X b}+\mathbf{W c}+\mathbf{Z a}+\mathbf{e}
$$

$$
\mathbf{y}=\mathbf{X b}+\mathbf{Z p}+\mathbf{Z a}+\mathbf{e}
$$

joissa $\mathbf{y}$ on havaintovektori, $\mathbf{b}$ on kiinteiden tekijöiden vektori ja $\mathbf{c}, \mathbf{a}, \mathbf{p}$ ja $\mathbf{e}$ ovat satunnaisten pentue-, additiivisten geneettisten, pysyvien ympäristövaikutusten ja jäännöstekijöiden vektorit, $\mathbf{X}, \mathbf{W}$ ja $\mathbf{Z}$ ovat niitä vastaavat insidenssimatriisit. Analyyseissä käytetyt kiinteät tekijät ovat taulukossa 2 . Gradeerausominaisuusille käytettiin satunnaistekijöinä additiivistä geneettistä tekijää sekä pentuetekijää. Pentuekoolle käytettiin additiivisen geneettisen tekijän lisäksi emän pysyviä ympäristötekijöitä. Satunnaistekijöiden oletettiin olevan toisistaan riippumattomia ja normaalisti jakautuneita: $\mathbf{a} \sim N\left(\mathbf{0}, \mathbf{A} \sigma_{a}^{2}\right), \mathbf{c} \sim N\left(\mathbf{0}, \mathbf{I} \sigma_{c}^{2}\right), \mathbf{p} \sim N\left(\mathbf{0}, \mathbf{I} \sigma_{p}^{2}\right), \mathbf{e} \sim N\left(\mathbf{0}, \mathbf{I} \sigma_{e}^{2}\right) . \quad$ Periytymisasteiden $\left(\mathrm{h}^{2}\right)$ pentuetekijän osuuksien $\left(\mathrm{c}^{2}\right)$ ja toistuvuuskertoimen (r) laskennassa käytettiin kaavoja: $h^{2}=\sigma_{a}^{2} /\left(\sigma_{a}^{2}+\sigma_{c}^{2}+\sigma_{e}^{2}\right), c^{2}=\sigma_{c}^{2} /\left(\sigma_{a}^{2}+\sigma_{c}^{2}+\sigma_{e}^{2}\right), \quad \mathrm{r}=\left(\sigma_{a}^{2}+\sigma_{p}^{2}\right) /\left(\sigma_{\mathrm{a}}^{2}+{ }_{\mathrm{p}}^{2}+\sigma_{\mathrm{e}}^{2}\right)$, joissa $\sigma_{a}^{2}=$ additiivinen geneettinen varianssi, $\sigma_{c}^{2}=$ pentuevarianssi, $\sigma_{p}^{2}=$ pysyvien ympäristötekijöiden varianssi ja $\sigma_{e}^{2}=$ jäännösvarianssi. 
Taulukko 2. Pentuekoolle sekä gradeerausominaisuuksille käytetyt kiinteät tekijät

\begin{tabular}{lcc}
\hline & Pentuekoko & Gradeeraus \\
\hline Tila-vuosi & $\mathrm{X}$ & $\mathrm{X}$ \\
Paritusten $\mathrm{lkm}$ & $\mathrm{X}$ & $\mathrm{X}$ \\
Syntymäajankohta vuoden alusta & & $\mathrm{X}$ \\
Emän ikä & & $\mathrm{X}$ \\
Naaraan ikä & $\mathrm{X}$ & $\mathrm{X}$ \\
Sukupuoli & & \\
\hline
\end{tabular}

\section{Tulokset}

Taulukossa 3 ovat tutkittavien ominaisuuksien perinnölliset tunnusluvut. Korkeimmat periytymisasteet arvioitiin värin tummuudelle ja puhtaudelle. Muissa ominaisuuksissa periytymisasteet jäivät alle 0,25. Pentuekoon toistuvuudeksi saatiin 0,15 . Pentuevaihtelun osuudet olivat melko alhaisia.

Taulukko 3. Pentuekoon sekä gradeerausominaisuuksien periytymisasteet $\left(\mathrm{h}^{2}\right)$, pentuevaihtelun osuus $\left(\mathrm{c}^{2}\right)$, toistuvuus (r) sekä fenotyyppiset varianssit $\left(\sigma_{f}^{2}\right)$, sekä estimaattien keskivirheet (SE)

\begin{tabular}{lcccc}
\hline Ominaisuus & $\sigma_{f}^{2}$ & $\mathrm{c}^{2} \pm \mathrm{SE}$ & $\mathrm{h}^{2} \pm \mathrm{SE}$ & $\mathrm{r}$ \\
\hline Pentuekoko & 4,06 & & $0,11 \pm 0,005$ & 0,15 \\
Eläimen koko & 0,48 & $0,10 \pm 0,003$ & $0,23 \pm 0,006$ & \\
Värin puhtaus & 0,44 & $0,08 \pm 0,009$ & $0,29 \pm 0,003$ & \\
Värin tummuus & 0,43 & $0,08 \pm 0,004$ & $0,39 \pm 0,008$ & \\
Massakkuus & 0,35 & $0,09 \pm 0,008$ & $0,17 \pm 0,004$ & \\
Peittävyys & 0,41 & $0,08 \pm 0,008$ & $0,22 \pm 0,004$ & \\
Laatu & 0,38 & $0,09 \pm 0,007$ & $0,19 \pm 0,004$ & \\
\hline
\end{tabular}

\section{Johtopäätökset}

Useimmat turkin laatua kuvaavat ominaisuudet ovat uudistetuilla malleilla lähellä vanhaa periytymisastetta $(0,20)$. Poikkeus on värin tummuus, jonka periytymisaste nousi lähes kaksinkertaiseksi. Myös värin puhtauden periytymisaste nousi selvästi. Eniten periytymisaste laski pentuekoolla. Saadut periytymisasteet ovat samansuuntaiset kuin aikaisemmissa minkkitutkimuksissa (Berg 1993, Lagerkvist 1994)

Aikaisempaa suuremmat heritabiliteetit kasvattivat ominaisuuksien jalostusarvojen hajontaa. Käytännössä eläinten väliset erot ovat suurempia. Eläinten keskinäisessä paremmuusjärjestyksessä tapahtuneet muutokset olivat kuitenkin maltillisia. Vaikka uusien mallien myötä eläinten jalostusarvot siis muuttuvat, käytännössä uudet minkkimallit vaikuttavat eläinten valintaan suhteellisen vähän. Muutosten suuruus vaihtelee tietenkin tiloittain, mutta keskimäärin muutokset ovat melko hillittyjä.

Uudet tilastolliset mallit ja varianssikomponentit otettiin käyttöön vuoden 2007 alussa. Jalostusarvostelua voidaan jatkossakin edelleen parantaa ottamalla huomioon muita korreloituneita ominaisuuksia. Erityisesti pentuekoon arvostelussa eläimen koon huomioiminen parantaisi arvostelun luotettavuutta 


\section{Kirjallisuus}

Berg, P. 1993. Present knowledge about heritability of different traits in mink. NJF Utredning/Rapport 90, NJF workshop, Viborg, Denmark. $10 \mathrm{~s}$.

Lagerqvist, G., Johansson K. \& Lundeheim N. 1994. Selection for litter size, body weight and pelt quality in mink (Mustela vison) Correlated responses. J. Anim. Sci. 72:1126-1137.

Lindh, K. \& Lohi, O. 1999. Analyses of pelt prices. Finnish production. Season 1998/1999. NJF utredningar Rapporter. Subsection for Pelsdyr / Avlsudvalget.

Lohi, O. 2002. Analyses of pelt prices. Finnish production. Season 2001/2002. NJF utredningar - Rapporter. Subsection for Pelsdyr / Avlsudvalget.

Madsen, P. \& Jensen, J. 2000. A user's quide to DMU, a package for analyzing multivariate mixed models, Danish Institute of Agricultural Sciences (DIAS). Tjele, Denmark. Mimeo 22 p.

Peura, J., Serenius T. ja Strandén, I. 2005. Economic weighs for most important traits in Finnish blue fox production. In: NJF Seminar no. 377. NJF's Subsection for Fur Animals, Uppsala, Sweden, 5-7 October 2005. $7 \mathrm{~s}$. 